\title{
Environmental stress and eutrophication in freshwater wetlands: evidence from carbon and nitrogen stable isotopes in cattail (Typha domingensis Pers.)
}

Ziye Zheng ${ }^{1}$, Yahong $\mathrm{Xu}^{1}$, Jianzhu Wang ${ }^{1,3^{*}}$, Yuncong $\mathrm{Li}^{2,3}$ and Binhe $\mathrm{Gu}^{3^{*}}$

\begin{abstract}
Background: Florida's Everglades is a vast freshwater peatland that has been impacted by the alterations of hydrological pattern and water quality which led to changes in plant species composition and biodiversity. In this study, carbon and nitrogen stable isotopes $\left(\delta^{13} \mathrm{C}\right.$ and $\delta^{15} \mathrm{~N}$ ) in cattail (Typha domingensis) are evaluated as indicators of environmental changes in the Everglades wetlands along nutrient and hydrological gradients represented by reference sites with total phosphorus (TP) $<10 \mu \mathrm{g} \mathrm{L}^{-1}$, transition sites with TP $\geq 10 \mu \mathrm{g} \mathrm{L}^{-1}<20 \mu \mathrm{g} \mathrm{L}^{-1}$ and impacted sites with $\mathrm{TP} \geq 20 \mu \mathrm{g} \mathrm{L}{ }^{-1}$ which differed in hydrology or habitats (marsh and canal).

Results: Cattail $\delta^{13} \mathrm{C}$ values decreased significantly from reference $(-24.1 \%)$, transition $(-26.8 \%)$ to the impacted sites $(-28.2 \%)$. In contrast, $\delta^{15} \mathrm{~N}$ values increased significantly from reference $(-5.2 \%)$, transition $(2.4 \%)$ to the impacted site (5.9\%). In response to a poor hydrological condition, cattail in marsh area displayed ${ }^{13} \mathrm{C}$ enrichment $\left(-26.0 \%\right.$ ) and ${ }^{15} \mathrm{~N}$ depletion $(0.2 \%)$. By contrast, cattail grown in the canal sites with favorable hydropattern displayed ${ }^{13} \mathrm{C}$ depletion $(-$ $27.6 \%$ ) and ${ }^{15} \mathrm{~N}$ enrichment (5.9\%) from the canal sites with more favorable hydrological condition.

Conclusions: The different patterns for the changes in $\delta^{13} \mathrm{C}$ and $\delta^{15} \mathrm{~N}$ in cattail suggested that increased nutrients led to increased stomatal conductance and ${ }^{13} \mathrm{C}$ fractionation during carbon uptake and decreased ${ }^{15} \mathrm{~N}$ fractionation with increasing nitrogen demand while poor hydrological condition coupled with low nutrients led to reduced plant growth indicated by higher $\delta^{13} \mathrm{C}$ and lower $\delta^{15} \mathrm{~N}$ values. Findings from this study suggested that $\delta^{13} \mathrm{C}$ in emerged macrophytes such as cattail can be used as an indicator for environmental stress while $\delta^{15} \mathrm{~N}$ is a robust indicator for wetland eutrophication.
\end{abstract}

Keywords: Cattail, Eutrophication, Everglades, Nutrient gradient, Phosphorus enrichment, Stable isotopes, Wetlands

\section{Introduction}

Florida's Everglades is the largest subtropical peatland in the USA with its historic geochemistry and biological community characterizing an oligotrophic ecosystem (Richardson 2010). Since human settlement, a large portion of the Everglades peatland immediately south of Lake Okeechobee was converted into farmlands, i.e.,

\footnotetext{
*Correspondence: gubinhe@gmail.com; gubinhe@gmail.com ${ }^{1}$ Engineering Research Center of Eco-environment in Three Gorges Reservoir Region, Ministry of Education, China Three Gorges University, Yichang 443002, China

${ }^{3}$ Soil and Water Science Department, University of Florida, 106 Newell Hall, Gainesville, FL 32611, USA

Full list of author information is available at the end of the article
}

Everglades Agricultural Area (EAA). The remaining Everglades has been divided into three Water Conservation Areas (WCA-1, WCA-2, and WCA-3) and Everglades National Park (ENP). Increased P loads have shifted portions of the ecosystem from oligotrophic to eutrophic states. The sawgrass in northern WCA-2A, an area that has received EAA discharge, has been replaced by cattail which was not present in large quantity in the historic Everglades (Sklar et al. 2005). To protect the biodiversity from further deterioration, several Stormwater Treatment Areas (STAs) have been constructed at the northern end of the EPA to treat EAA runoff for P removal (Chimney and Goforth 2006). 
Current indicators of environmental changes for the Everglades as well as for other aquatic systems focus on the impacts of nutrient loading such as soil and water total $\mathrm{P}(\mathrm{TP})$ and total $\mathrm{N}(\mathrm{TN})$ concentrations, species composition, biomass, and primary production (Newman et al. 1996; Sklar et al. 2002, 2005; Wright et al. 2008). These indicators often reveal the changes in the impacted systems that have taken place. Ecological research and restoration efforts indicate that it is extremely difficult to restore ecosystems that have been severely disturbed. Therefore, the identification of early symptoms of environmental change, prior to major damage, is critical for the restoration of disturbed systems to conserve natural resources (Mwaura et al. 2017).

Carbon and nitrogen stable isotope compositions $\left(\delta^{13} \mathrm{C}\right.$ and $\left.\delta^{15} \mathrm{~N}\right)$ of biota may be an alternative means to detect early environmental changes in aquatic ecosystems (Oczkowski et al. 2014; Wang et al. 2015; Gooddy et al. 2016; Nigro et al. 2017) and can provide insight into the sources, sinks, and cycling of carbon and nitrogen in biota that interact with their physical and chemical environments. Several studies have indicated that $\delta^{13} \mathrm{C}$ and $\delta^{15} \mathrm{~N}$ values can be used as early indicators for environmental changes (McKee et al. 2002; Wang et al. 2015; Zhang et al. 2016; Nigro et al. 2017). The ${ }^{13} \mathrm{C}$ depletion in the mangrove trees has been attributed to reduced stomatal conductance under environmental stressors such as nutrients and salinity (Lin and Sternberg 1992; McKee et al. 2002). Inglett and Reddy (2006) found different responses of $\delta^{13} \mathrm{C}$ in sawgrass and cattail along a nutrient gradient of the WCA-2A of the Florida Everglades.

The $\delta^{15} \mathrm{~N}$ values of various plant species have been used as indicators for the sources and magnitude of wastewater discharge into estuaries and coast ecosystems (Cole et al. 2004; Savage 2005; Lapointe et al. 2015; Mancinelli and Vizzini 2015) and inland waters (Hall et al. 1999; Lake et al. 2001). Biota $\delta^{15} \mathrm{~N}$ has also been used as an indicator of eutrophication, especially under increased P loading. Studies show that primary producers respond to $\mathrm{P}$ enrichment with rapid $\mathrm{N}$ uptake, thereby resulting in decreases in ${ }^{15} \mathrm{~N}$ fractionation. Inglett and Reddy (2006) found higher $\delta^{15} \mathrm{~N}$ in cattail than in sawgrass along a P gradient in WCA-2A and attributed the difference to the faster growth of cattail compared to sawgrass. Chang et al. (2009) found that sawgrass $\delta^{15} \mathrm{~N}$ is correlated with cattail $\delta^{15} \mathrm{~N}$ in WCA-1, suggesting similar responses to environmental variations in the two macrophytes.

The present study compared $\delta^{13} \mathrm{C}$ and $\delta^{15} \mathrm{~N}$ in cattail (Typha domingensis Pers.) collected from the reference, transition, and impacted sites in south Florida wetlands. Cattail was chosen to test if stable isotope variations along the hydrological and nutrient gradients can be used to infer environmental stress and nutrient enrichment. It also provides insightful information on factors controlling isotope composition in cattail community.

\section{Materials and methods Site description}

A total of 14 sites, with 2 sites in STA-1W and 12 sites in STAs and WCAs (Fig. 1) were used in this analysis. These sites were located at canals or marshes where water depth, retention time, nutrients, and other environmental conditions differed among sites (Table 4 in Appendix). Study sites at cell 3 and cell 4 of the STA-1W, and E0 and F1 of WCA-2A (impacted sites) that received direct EAA discharges are highly enriched with TP $\left(>20 \mu \mathrm{g} \mathrm{L}^{-1}\right)$. Study sites located immediately downstream of STA-1W, WCAs, or close to interior canals (transition sites) are moderately enriched with TP (>10 and $\leq 20 \mu \mathrm{g} \mathrm{L}^{-1}$ ). Interior marshes (reference sites) in WCAs typically maintain the oligotrophic state indicated by a low TP concentration $\left(\leq 10 \mu \mathrm{g} \mathrm{L}^{-1}\right)$. Total $\mathrm{N}$ and dissolved inorganic $\mathrm{N}$ (DIN) concentrations were also higher at the near inflow sites than the marsh interior sites, except for U3, the interior site of WCA-2A, which is enriched with ammonium and TN. All study sites are generally characterized by above-neutral pH (Table 4 in Appendix).

\section{Sources of data}

There are several sources of data used in this study. Stable isotope data on cattail were downloaded from the US Geological Survey South Florida Information Access (https:// sofia.usgs.gov/metadata/sflwww/ever_isotope_data.html) and Wang et al. (2015). Typically, duplicate to triplicate samples were collected from each site for stable isotope determination. Select environmental data (Table 4 in Appendix) from the same time period (1995 to 2009) of the stable isotope data collection were downloaded from DBHYDRO, a hydrometeorologic, water quality, and hydrogeologic data retrieval system managed by the South Florida Water Management District (West Palm Beach Florida, USA), Miao and Sklar (1997) and Wang et al. (2015). When environmental data were not available from the same site of cattail collection, data from closely located sites were used.

\section{Statistical analysis}

Statistical analysis was conducted using the SigmaPlot 13.0 software (Systat Software, Inc). Data were tested for normality using the Shapiro-Wilk normality test and equal variance test (Brown-Forsythe) before an analysis was performed. Cattail isotope data from different sites or habitats were analyzed by analysis of variance (ANOVA). For data that did not pass normality and equal variance test, the Kruskal-Wallis ANOVA on ranks was used, followed by Dunn's method or Tukey test. 


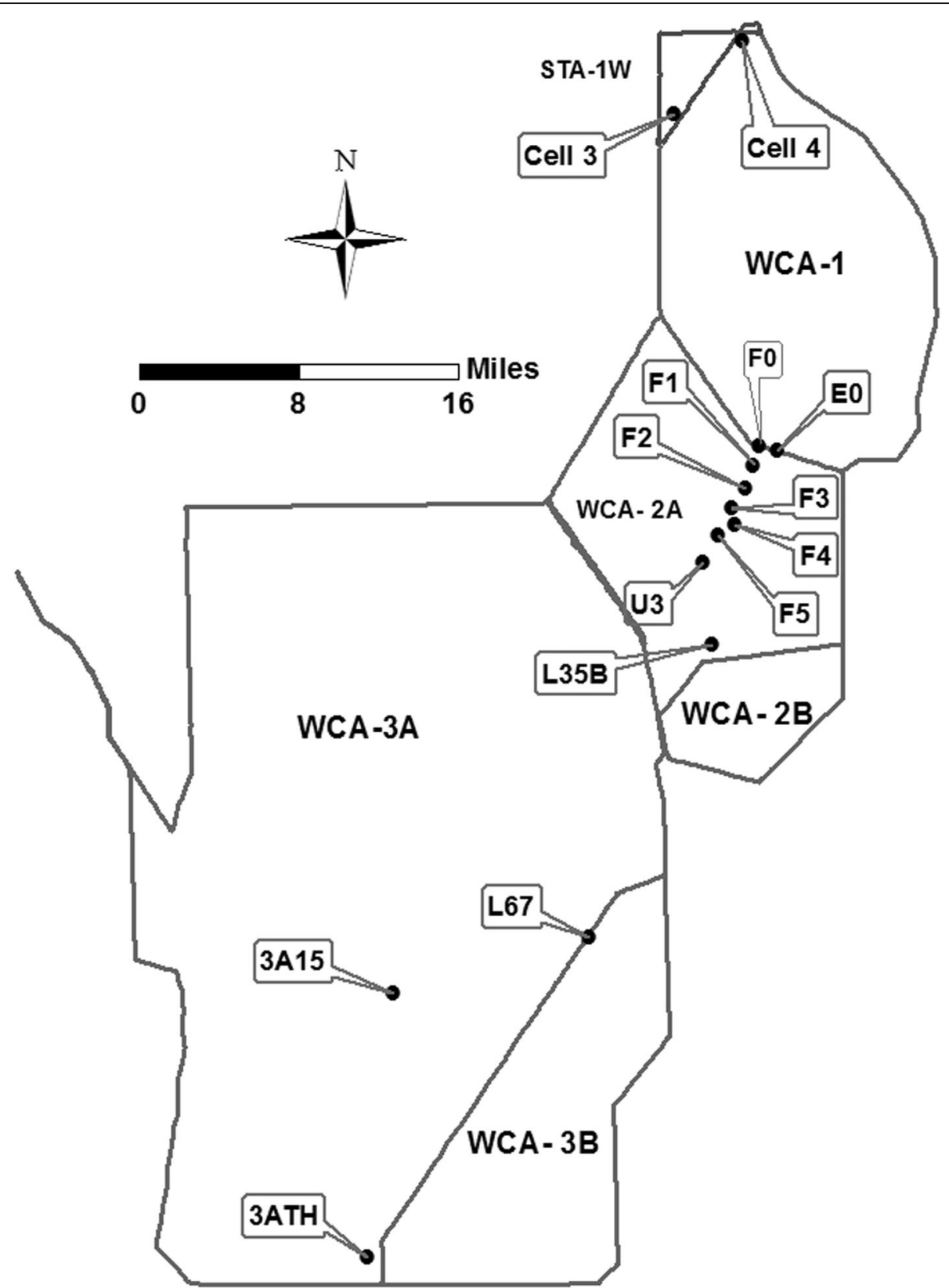

Fig. 1 Map showing sampling sites in Stormwater Management Area 1 West (STA-1W) and Water Conservation Areas (WCAs) in south Florida, USA

Spearman's rank correlation was used to test significant trends. Statistics were considered significant at $p<0.05$.

\section{Results}

Environmental characteristics along nutrient gradient

A summary of select environmental variables grouped by reference, transition, and impacted sites are presented in Table $1(N=14$ sites). Significant differences in TP concentration were found among reference, transition, and impacted sites. TP concentration at the transition sites was twice as high as the reference sites while TP concentration at the impacted sites was over three folds greater than the transition sites. Similarly, there were significant differences in soluble reactive phosphorus (SRP) concentration along the nutrient gradient. Despite there were tendencies with a progressive increase in $\mathrm{TN}$, DIN, and $\mathrm{pH}$ from reference, transition to impacted sites, differences among these sites were not significant $(p>0.05)$.

Table 2 presented several biological and nutrient variables along the nutrient gradient from inflow to interior marsh in WCA-2A (the F transect, Fig. 1) obtained from 
Table 1 Average nutrient and environmental variables and ANOVA results in reference, transition and impacted sites of several south Florida wetlands

\begin{tabular}{|c|c|c|c|c|c|}
\hline \multirow{2}{*}{ Variable } & \multicolumn{3}{|c|}{ Nutrient zone } & \multicolumn{2}{|c|}{ ANOVA } \\
\hline & Reference & Transition & Impacted & $\bar{F}$ & P \\
\hline$\overline{\mathrm{TP}}\left(\mu \mathrm{g} \mathrm{L^{-1 }}\right)$ & $6.3 \pm 1.5$ & $13.7 \pm 1.1$ & $46.2 \pm 22.3$ & 7.23 & 0.013 \\
\hline $\mathrm{TN}\left(\mathrm{mg} \mathrm{L}^{-1}\right)$ & $1.5 \pm 0.5$ & $1.6 \pm 0.2$ & $2.3 \pm 0.5$ & 3.47 & 0.076 \\
\hline $\operatorname{SRP}\left(\mu g L^{-1}\right)$ & $1.3 \pm 0.6$ & $4.7 \pm 0.6$ & $17.5 \pm 13.4$ & 7.94 & 0.004 \\
\hline $\operatorname{DIN}\left(\mu \mathrm{g} \mathrm{L}^{-1}\right)$ & $0.12 \pm 0.14$ & $0.19 \pm 0.20$ & $0.30 \pm 0.20$ & 2.89 & 0.264 \\
\hline TN:TP (molar ratio) & $562 \pm 350$ & $259 \pm 34$ & $126 \pm 48$ & 9.34 & $\leq 0.001$ \\
\hline $\mathrm{pH}(\mathrm{SU})$ & $7.0 \pm 0.6$ & $7.1 \pm 0.1$ & $7.3 \pm 0.1$ & 0.77 & 0.49 \\
\hline Sulfate $\left(\mathrm{mg} \mathrm{L}^{-1}\right)$ & $20.1 \pm 32.0$ & $16.3 \pm 11.9$ & $47.6 \pm 13.4$ & 3.63 & 0.07 \\
\hline
\end{tabular}

the literature (Miao and Sklar 1997; Wang et al. 2015). Data were grouped into reference, transition, and impacted sites as described above. Average cattail plant height was lowest at the reference, intermediate at transition, and highest at the impacted sites. Similarly, the photosynthetic rate measured for cattail increased along the nutrient gradient. Surface water and soil TP also displayed a trend of increases along the transect. Surface water TN decreased slightly while soil TN increased slightly along the transect (Table 2).

\section{Variations in cattail $\delta^{13} \mathrm{C}$ and $\delta^{15} \mathrm{~N}$}

Average cattail $\delta^{13} \mathrm{C}$ values decreased significantly from reference $(-24.1 \%$ o), transition $(-26.8 \%$ o $)$ to the impacted sites $(-28.2 \%$ ) (ANOVA, $F=23.5$, df $=2, p<0.001$ ). Pairwise multiple comparisons indicated significant differences for all sites (Fig. 2a). By contrast, average cattail $\delta^{15} \mathrm{~N}$ values increased significantly from reference $(-5.3 \%)$, transition (2.4\%o) to the impacted site (6.0\%o) (ANOVA, $F=17.6, \mathrm{df}=2, p<0.001$ ). Pairwise multiple comparisons indicated significant differences for all sites (Fig. 2b). Similar to stable isotope responses to nutrient enrichment, cattail $\delta^{13} \mathrm{C}$ and $\delta^{15} \mathrm{~N}$ increased and decreased, respectively, as soil molar TN:TP ratio increased

Table 2 Mean biomass, height and photosynthesis rate of cattail and surface water and soil nutrients in reference, transition, and impacted zone of the Florida Everglades (Water Conservation Area 2A). Except data for cattail photosynthesis (Wang et al. 2015), all data are taken from Miao and Sklar (1997)

\begin{tabular}{llll}
\hline Variable & Reference & Transition & Impacted \\
\hline Plant height $(\mathrm{cm})$ & 220 & 230 & 260 \\
$\begin{array}{l}\text { Photosynthesis rate } \\
\left(\mu \mathrm{mol} \mathrm{CO} \mathrm{m}^{-2} \mathrm{~s}^{-1}\right)\end{array}$ & $10.4 \pm 0.5$ & $14.3 \pm 0.6$ & $23.5 \pm 1.6$ \\
$\begin{array}{l}\text { Surface water } \\
\text { TP }\left(\mathrm{mg} \mathrm{L}^{-1}\right)\end{array}$ & $0.061 \pm 0.007$ & $0.011 \pm 0.001$ & $0.005 \pm 0.001$ \\
$\begin{array}{l}\text { Surface water } \\
\text { TN }\left(\mathrm{mg} \mathrm{L}^{-1}\right)\end{array}$ & $2.4 \pm 0.1$ & $2.2 \pm 0.0$ & $2.1 \pm 0.1$ \\
Soil TP $\left(\mathrm{mg} \mathrm{kg}^{-1}\right)$ & $441 \pm 78$ & $720 \pm 89$ & $1305 \pm 105$ \\
Soil TN $\left(\mathrm{mg} \mathrm{kg}^{-1}\right)$ & $27.2 \pm 2.8$ & $28.2 \pm 1.2$ & $31.1 \pm 0.7$ \\
\hline
\end{tabular}

(Fig. 3a, b). When data from all sites were pooled, several significant correlations between cattail stable isotope values and nutrients are found (Table 3). Cattail $\delta^{13} \mathrm{C}$ values were negatively correlated with $\delta^{15} \mathrm{~N}$ and TP concentrations, but positively correlated with molar TN/TP

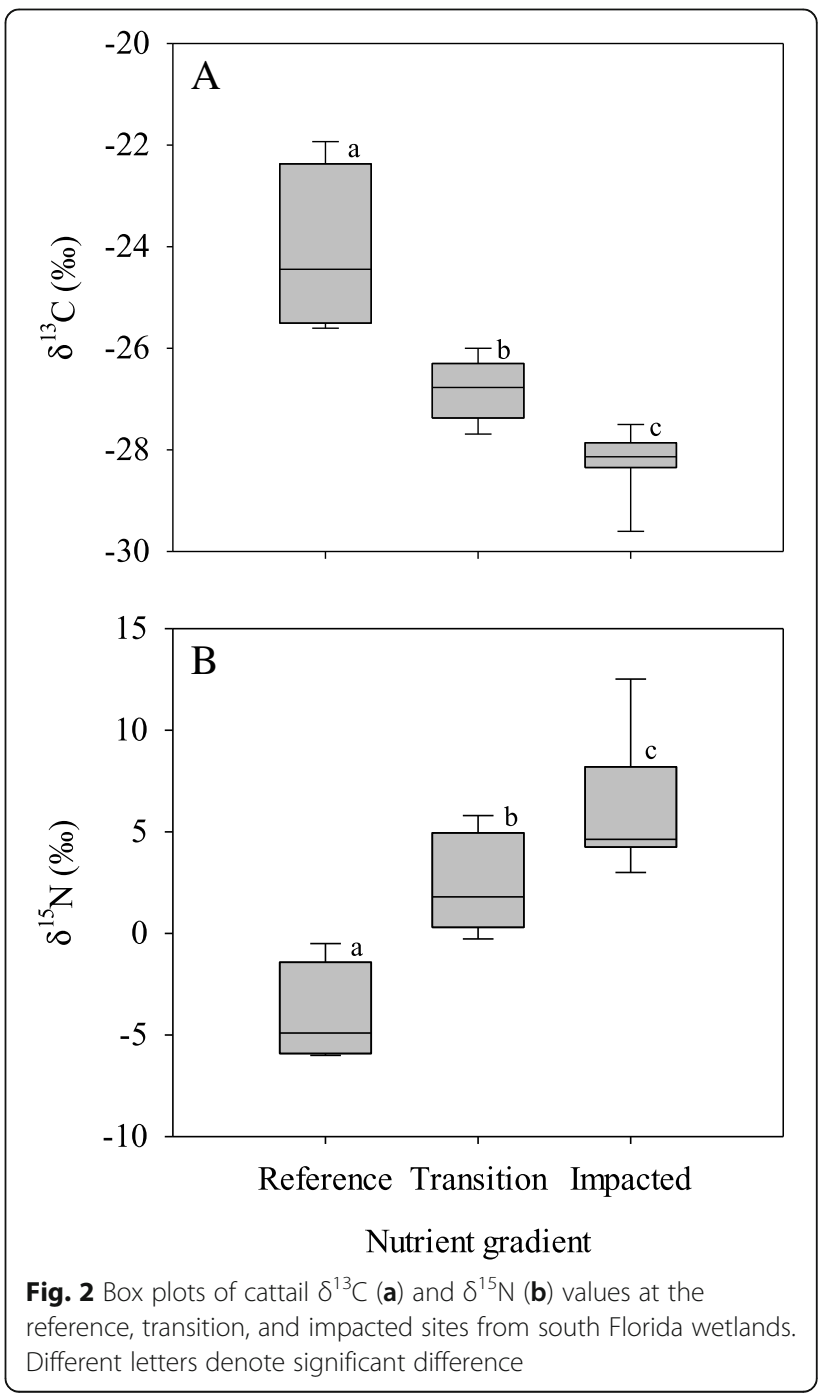



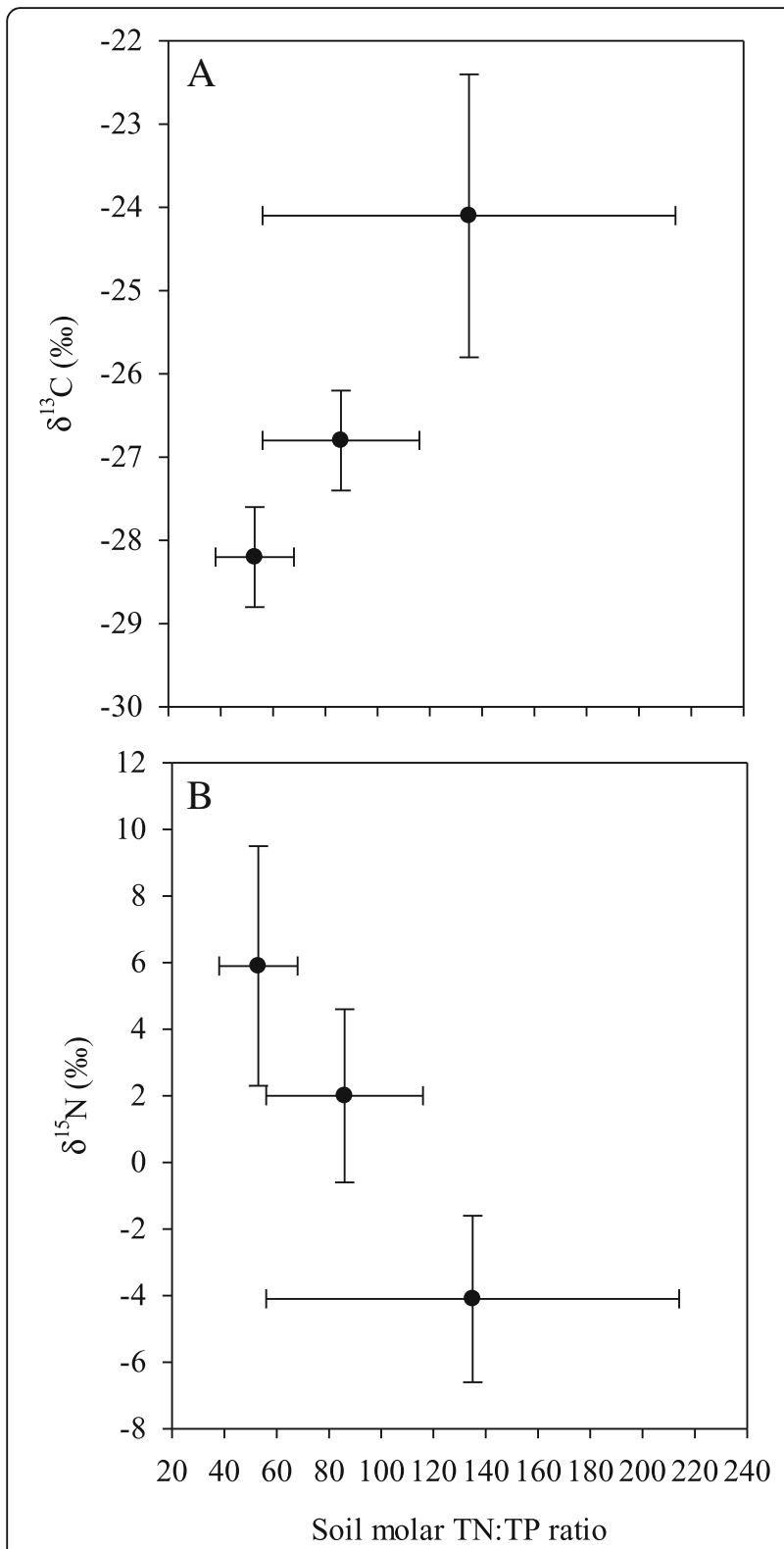

Fig. 3 Changes in cattail $\delta^{13} \mathrm{C}(\mathbf{a})$ and $\delta^{15} \mathrm{~N}(\mathbf{b})$ and soil total nitrogen (TN):total phosphorus (TP) ratios (mean $\pm \mathrm{SD}$ ) measured along the nutrient gradient in south Florida

ratios. Cattail $\delta^{15} \mathrm{~N}$ values were positively correlated with TP concentrations and negatively correlated with TN/TP ratios. Correlation between $\mathrm{TN}, \delta^{13} \mathrm{C}$, and $\delta^{15} \mathrm{~N}$ was not significant.

When data were grouped by habitats, $\delta^{13} \mathrm{C}$ and $\delta^{15} \mathrm{~N}$ values differed significantly between the marsh and canal sites (Fig. 4a, b). Average cattail $\delta^{13} \mathrm{C}$ values are higher $(-26.0 \%)$ in marsh area than in canal $(-27.6 \%)(F=6.65$, $p=0.024)$. By contrast, average cattail $\delta^{15} \mathrm{~N}$ value was depleted in the marsh $(0.2 \%)$ than from the canal sites $(5.9 \%$ o $)(F=6.80, p=0.023)$. There were no significant
Table 3 Spearman rank correlation between stable isotope values and select environmental variables, $N=14$ sites

\begin{tabular}{lllll}
\hline & $\delta^{15} \mathrm{~N}$ & $\delta^{13} \mathrm{C}$ & $\mathrm{TP}$ & $\mathrm{TN}$ \\
\hline$\delta^{13} \mathrm{C}$ & $-0.81^{* * *}$ & & & \\
$\mathrm{TP}$ & $0.70^{* *}$ & $-0.76^{* *}$ & & \\
$\mathrm{TN}$ & 0.23 & -0.28 & $0.65^{*}$ & \\
$\mathrm{~N} / \mathrm{P}$ & $-0.80^{* * *}$ & $0.79^{* * *}$ & $-0.95^{* * *}$ & $-0.52^{*}$ \\
\hline
\end{tabular}

Note: ${ }^{* *} p<0.001,{ }^{* *} p<0.01,{ }^{*} p<0.05$

differences in TP or TN between the marsh and canal sites (Fig. 4c, d).

\section{Discussion}

\section{Responses of cattail $\delta^{13} \mathrm{C}$ to nutrient enrichment}

Similar to terrestrial plants, emergent aquatic plants use atmospheric $\mathrm{CO}_{2}$ which is well mixed worldwide. Therefore, substrate effects (concentration and isotope baseline) during $\mathrm{C}$ uptake can be eliminated as causes for cattail isotope changes along nutrient gradient. The $\delta^{13} \mathrm{C}$ values of cattail collected from STAs and WCAs in south Florida decreased from reference to the impacted sites. Chang et al. (2009) and Wang et al. (2015) also found a negative relationship between soil TP and cattail $\delta^{13} \mathrm{C}$ in WCA-1 and WCA-2A. We attribute the $\delta^{13} \mathrm{C}$ enrichments of cattail at the impacted marshes of the Everglades to reduced isotopic fractionation due to low stomatal conductance under environmental stress. Similar observations have been reported for scrub or dwarf red mangrove (Rhizophora mangle) growing in P-limited areas (Lin and Sternberg 1992; McKee et al. 2002). Miao et al. (1997) reported that the photosynthetic rate of sawgrass seedlings from the Everglades was a function of stomatal conductance in a nutrient addition experiment. With the increases in $\mathrm{P}$ concentrations and photosynthetic rate, plant stomatal conductance increases, reducing restriction to $\mathrm{CO}_{2}$ transport into the carboxylation sites, which may lead to higher ${ }^{13} \mathrm{C}$ fractionation. Conversely, under $\mathrm{P}$ stress, emergent plants reduce their stomatal conductance, making $\mathrm{CO}_{2}$ diffusion a ratelimited process, which in turn results in reduced ${ }^{13} \mathrm{C}$ fractionation. Low photosynthetic rates in the nutrientpoor environment may result in larger ${ }^{13} \mathrm{C}$ fractionation. Apparently, the cattail ${ }^{13} \mathrm{C}$ enrichment in the reference sites is controlled more by stomatal conductance $\left(\mathrm{CO}_{2}\right.$ availability) than carboxylation rate $\left(\mathrm{CO}_{2}\right.$ demand). This is verified in a recent study reported by Wang et al. (2015) who found that cattail $\delta^{13} \mathrm{C}$ decreased as the photosynthetic rate increased along the nutrient gradient in WCA-2A. These results demonstrated that the $\delta^{13} \mathrm{C}$ of emergent macrophytes such as cattail is a sensitive indicator for environmental stress, such as P deficiency in freshwater wetlands, consistent with the studies conducted 

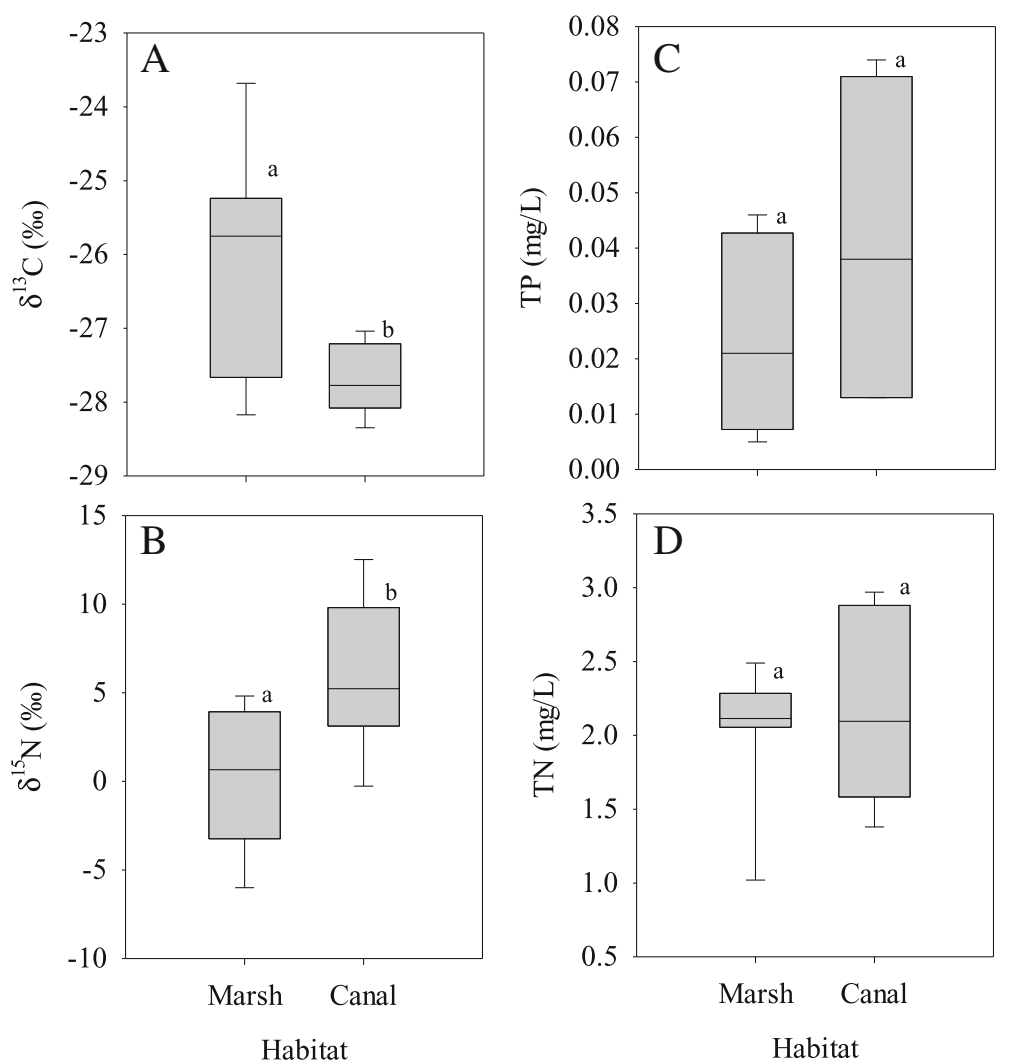

Fig. 4 Cattail $\delta^{13} \mathrm{C}(\mathbf{a})$ and $\delta^{15} \mathrm{~N}(\mathbf{b})$, and surface water TP $(\mathbf{c})$ and TN $(\mathbf{d})$ in marsh $(N=8)$ and canal sites $(N=6)$ from south Florida. Different letters denote significant difference

in the mangrove forest (Lin and Sternberg 1992; McKee et al. 2002).

\section{Responses of cattail $\delta^{15} \mathrm{~N}$ to nutrient enrichment}

The cattail $\delta^{15} \mathrm{~N}$ may be controlled by various factors including the sources of $\mathrm{N}$ with different $\delta^{15} \mathrm{~N}$ values, the concentration of DIN, and the growth rate which is affected greatly by $\mathrm{P}$ availability, plant physiology, and the underwater light condition. Nitrogen from human and animal wastes is enriched in $\delta^{15} \mathrm{~N}$ (McClelland et al. 1997). Enriched $\delta^{15} \mathrm{~N}$ of various taxa has been used as an indicator for sewage influence in the freshwater and coastal marine environments (Cole et al. 2004; Nixon et al. 2007; Bannon and Roman 2008; Orlandi et al. 2014; Lapointe et al. 2015). There have been no reports of any significant wastewater contributions from human or animal sources to the Everglades. In fact, Inglett and Reddy (2006) reported a similar $\delta^{15} \mathrm{~N}$ of porewater $\mathrm{NH}_{4}{ }^{+}(\sim 7 \%)$ in the impacted and unimpacted areas in WCA-2A. Therefore, the high $\delta^{15} \mathrm{~N}$ at the impacted sites is not the result of uptake of wastewater enriched with ${ }^{15} \mathrm{~N}$.

Dissolved inorganic nitrogen concentration may also influence cattail $\delta^{15} \mathrm{~N}$ through a substrate-mediated isotope effect (Peterson and Fry 1987). An increase in N concentration will normally lead to an increase in isotopic fractionation and therefore a decrease in plant tissue $\delta^{15} \mathrm{~N}$. However, across the nutrient gradient, changes in DIN concentrations were not significant (Table 1). The high molar ratios of TN:TP which is greater than $16 \mathrm{im}$ plies that $\mathrm{N}$ is not a limiting nutrient to plant growth in the Everglades. The negative correlation between the water column TN:TP ratio and cattail $\delta^{15} \mathrm{~N}$ also indicates that $\mathrm{P}$, not $\mathrm{N}$, is the limiting nutrient in the Everglades.

The major external source of $\mathrm{N}$ in the Everglades is an agricultural runoff. Because manufactured fertilizers are depleted in ${ }^{15} \mathrm{~N}$ (Kohl et al. 1971), assimilation of this ${ }^{15} \mathrm{~N}$-depleted $\mathrm{N}$ will not result in ${ }^{15} \mathrm{~N}$ enrichment in the impacted sites. We conclude that the ${ }^{15} \mathrm{~N}$ enrichment in cattail at the impacted sites of the Everglades is the result of increased plant growth stimulated by $\mathrm{P}$ availability. The cattail low $\delta^{15} \mathrm{~N}$ at the reference sites was the result of slow growth and large ${ }^{15} \mathrm{~N}$ fractionation under $\mathrm{P}$ stress. The high $\mathrm{N}$ availability at the reference sites also allowed selective assimilation of ${ }^{14} \mathrm{~N}$ by cattail, further lowering the tissue $\delta^{15} \mathrm{~N}$. Similarly, low $\delta^{15} \mathrm{~N}$ in the transition and dwarf trees of the red mangrove was attributed to low $\mathrm{N}$ demand (McKee et al. 2002). Mwaura et al. (2017) also reported an apparent onshoreoffshore gradient in macrophyte $\delta^{15} \mathrm{~N}$ stimulated by terrestrial loading of nutrients. In contrast, the high $\delta^{15} \mathrm{~N}$ 
at the impacted sites was due to $\mathrm{P}$ enrichment which leads to high $\mathrm{N}$ demand and low ${ }^{15} \mathrm{~N}$ fractionation. Many studies have demonstrated that $\mathrm{P}$ is the limiting nutrient in the Everglades (Newman et al. 1996; Smith et al. 2009). Recent studies using stable isotopes found a positive relationship between TP and $\delta^{15} \mathrm{~N}$ of periphyton, sawgrass, and cattail in WCA-1 and WCA-2A, which was attributed to P-driven plant growth and reduced isotope fractionation (Inglett and Reddy 2006; Chang et al. 2009).

\section{Responses of cattail $\delta^{13} \mathrm{C}$ and $\delta^{15} \mathrm{~N}$ to changes in hydropattern}

Water depth and duration may affect the growth of aquatic plants which in turn affects tissue $\delta^{13} \mathrm{C}$ and $\delta^{15} \mathrm{~N}$. Newman et al. (1996) demonstrated that water depth and duration of flooding significantly impact cattail expansion in two south Florida wetlands. In the Everglades, marsh typically has shallower water depth and shorter hydroperiod than canals. Compared to cattail grown in the marsh, ${ }^{13} \mathrm{C}$ depletion in the canal habitat may suggest that high growth rate led to plant stomatal conductance increases, reducing restriction to $\mathrm{CO}_{2}$ transport into the carboxylation sites, leading to higher ${ }^{13} \mathrm{C}$ fractionation. By contrast, slow-growth cattail in the marsh habitat requires less $\mathrm{CO}_{2}$ to support photosynthesis, resulting in less isotope fractionation. The effects on cattail $\delta^{13} \mathrm{C}$ along the hydrological gradient are similar to those along the nutrient gradient: environmental stress may lead to less isotope fractionation due to reduced substrate demand (Lin and Sternberg 1992; McKee et al. 2002; Wang et al. 2015).

The $\delta^{15} \mathrm{~N}$ in cattail grown in the canal habitat was significantly higher than that in the marsh habitat. Both TP and TN concentrations did not differ significantly between the marsh and canal habitat although the average TP concentration at the canal sites was twice high as that in the marsh. Cattail growth in the canal habitat was stimulated by more favorable hydropattern than those grown in the marsh sites. Apparently, high $\mathrm{N}$ uptake results in reduced isotope fractionation (Peterson and Fry 1987; Dawson et al. 2002). More research is needed to understand the interactive relationship between nutrients, hydrology, plant growth, and $\delta^{15} \mathrm{~N}$ in cattail under different hydrological and nutrient scenarios.

\section{Conclusions}

Human influences have led to multiple ecosystem changes. This study demonstrates that stable isotopes are generally sensitive environmental indicators and can be used to assess the responses of aquatic plants to nutrient stress, enrichment, and water management. The ${ }^{13} \mathrm{C}$ enrichment in cattail from the pristine marsh is an indicator for nutrient stress which is reduced at transition and especially the impacted sites as $\delta^{13} \mathrm{C}$ become depleted due to increases in gas conductance. This conclusion is consistent with the findings from the studies of red mangrove isotope composition along salinity and nutrient gradients. The eutrophication process resulting from excessive $\mathrm{P}$ loading from the agricultural runoff to the Everglades is best demonstrated using cattail $\delta^{15} \mathrm{~N}$ which responded positively to the increases in TP concentration. Similar responses of cattail $\delta^{13} \mathrm{C}$ and $\delta^{15} \mathrm{~N}$ to hydrological changes were also identified in this work. Further study needs to understand the role of each factor (nutrient and hydrology) in controlling $\delta^{15} \mathrm{~N}$ in cattail along the nutrient and hydrological gradient.

\section{Appendix}

Table 4 Averages of environmental variables for each study site (see Fig. 1 for site location) during the study period

\begin{tabular}{llllllll}
\hline Site & $\mathrm{pH}$ & $\mathrm{TP}$ & $\mathrm{SRP}$ & $\mathrm{DIN}$ & $\mathrm{TN}$ & $\begin{array}{l}\text { TN:TP } \\
\text { Molar ratio }\end{array}$ & $\begin{array}{l}\text { Habitat } \\
\text { type }\end{array}$ \\
\hline Cell 3 & 7.4 & 42 & 16 & 0.18 & 2.05 & 108 & Marsh \\
Cell 4 & 7.1 & 46 & 12 & 0.20 & 2.07 & 99 & Marsh \\
E0 & 7.1 & 74 & 41 & 0.48 & 2.97 & 89 & Canal \\
F0 & 7.4 & 137 & 2 & 0.84 & 2.44 & 39 & Canal \\
F1 & 7.3 & 99 & 3 & 0.08 & 2.99 & 67 & Marsh \\
F2 & 7.3 & 75 & 3 & 0.10 & 2.49 & 73 & Marsh \\
F3 & 7.3 & 30 & 2 & 0.08 & 2.32 & 171 & Marsh \\
F4 & 7.3 & 24 & 2 & 0.03 & 2.09 & 197 & Marsh \\
F5 & 7.4 & 11 & 2 & 0.06 & 2.14 & 425 & Marsh \\
L35B & 7.20 & 13 & 5 & 0.09 & 1.75 & 298 & Canal \\
L67 & 7.00 & 15 & 5 & 0.43 & 1.65 & 238 & Canal \\
3ATH & 7.20 & 13 & 4 & 0.10 & 1.38 & 242 & Marsh \\
3A15 & 7.10 & 6 & 1 & 0.04 & 1.02 & 401 & Marsh \\
U3 & 7.50 & 5 & 2 & 0.28 & 2.18 & 964 & Marsh \\
\hline
\end{tabular}

\section{Acknowledgements}

We appreciate the United States Geological Survey and the South Florida Water Management District for providing stable isotope and water quality data.

\section{Authors' contributions}

$\mathrm{YX}$ and $\mathrm{ZZ}$ analyzed the data and wrote the manuscript. BG revised the manuscript. JW and YL provided scientific editorial advice. All authors read and approved the final manuscript.

Funding

This study was supported from an Overseas Research collaboration grant (2018AHB020) funded by Hubei Province, China.

Availability of data and materials

All data used in this manuscript will be available upon request.

Ethics approval and consent to participate

Not applicable. This is a literature data analysis. 


\section{Consent for publication}

Not applicable

\section{Competing interests}

The authors declare that they have no competing interests.

\section{Author details}

'Engineering Research Center of Eco-environment in Three Gorges Reservoir Region, Ministry of Education, China Three Gorges University, Yichang 443002, China. ${ }^{2}$ Tropical Research and Education Center, University of Florida, 18905 SW 280th St. Homestead, Gainesville, FL 33031, USA. ${ }^{3}$ Soil and Water Science Department, University of Florida, 106 Newell Hall, Gainesville, FL 32611, USA.

Received: 27 March 2019 Accepted: 28 June 2019

Published online: 06 August 2019

\section{References}

Bannon RO, Roman CT (2008) Using stable isotopes to monitor anthropogenic nitrogen inputs to estuaries. Ecol Appl 18:22-30

Chang CCY, McCormick PV, Newman S (2009) Isotopic indicators of environmental change in a subtropical wetland. Ecol Indic 9:825-836

Chimney MJ, Goforth G (2006) History and description of the Everglades Nutrient Removal Project, a subtropical constructed wetland in south Florida (USA). Ecol Eng 27:268-278

Cole ML, Valiela I, Kroeger KD (2004) Assessment of a $\delta^{15} \mathrm{~N}$ isotopic method to indicate anthropogenic eutrophication in aquatic ecosystems. J Environ Qual 33:124-132

Dawson TE, Mambelli S, Plamboeck AH (2002) Stable isotopes in plant ecology. Annu Rev Ecol Evol Syst 33:507-559

Gooddy DC, Lapworth DJ, Bennett SA (2016) A multi-stable isotope framework to understand eutrophication in aquatic ecosystems. Water Res 88:623-633

Hall Rl, Leavitt PR, Quinlan R (1999) Effects of agriculture, urbanization, and climate on water quality in the northern Great Plains. Limnol Oceanogr 44: 739-756

Inglett PW, Reddy KR (2006) Investigating the use of macrophyte stable C and N isotopic ratios as indicators of wetland eutrophication: patterns in the P-affected Everglades. Limnol Oceanogr 51:2380-2387

Kohl DH, Shearer GB, Commoner B (1971) Fertilizer nitrogen: contribution to nitrate in surface water in a corn belt watershed. Science 174:1331-1334

Lake JL, McKinney RA, Osterman FA (2001) Stable nitrogen isotopes as indicators of anthropogenic activities in small freshwater systems. Can J Fish Aquat Sci 58:870-878

Lapointe BE, Herren LW, Debortoli DD (2015) Evidence of sewage-driven eutrophication and harmful algal blooms in Florida's Indian River Lagoon. Harmful Algae 43:82-102

Lin GH, Sternberg LSL (1992) Effect of growth form, salinity, nutrient and sulfide on photosynthesis, carbon isotope discrimination and growth of red mangrove (Rhizophora mangle L.). Funct Plant Biol 19:509-517

Mancinelli G, Vizzini S (2015) Assessing anthropogenic pressures on coastal marine ecosystems using stable CNS isotopes: state of the art, knowledge gaps, and community-scale perspectives. Estuar Coast Shelf Sci 156:195-204

McClelland JW, Valiela I, Michener RH (1997) Nitrogen-stable isotope signatures in estuarine food webs: a record of increasing urbanization in coastal watersheds. Limnol Oceanogr 42:930-937

McKee KL, Feller IC, Popp M (2002) Mangrove isotopic $\left(\delta^{15} \mathrm{~N}\right.$ and $\left.\delta^{13} \mathrm{C}\right)$ fractionation across a nitrogen vs. phosphorus limitation gradient. Ecology 83:1065-1075

Miao SL, Borer RE, Sklar FH (1997) Sawgrass seedling responses to transplanting and nutrient additions. Restor Ecol 5:162-168

Miao SL, Sklar FH (1997) Biomass and nutrient allocation of sawgrass and cattail along a nutrient gradient in the Florida Everglades. Wetl Ecol Manag 5:245-264

Mwaura J, Umezawa Y, Nakamura T (2017) Evidence of chronic anthropogenic nutrient within coastal lagoon reefs adjacent to urban and tourism centers, Kenya: a stable isotope approach. Mar Pollut Bull 119:74-86

Newman S, Grace JB, Koebel JW (1996) Effects of nutrients and hydroperiod on typha, cladium, and eleocharis: implications for Everglades restoration. Ecol Appl 6:774-783

Nigro KM, Hathaway SA, Wegmann AS (2017) Stable isotope analysis as an early monitoring tool for community-scale effects of rat eradication. Restor Ecol 25:1015-1025
Nixon SW, Buckley BA, Granger SL (2007) Anthropogenic enrichment and nutrients in some tropical lagoons of Ghana, West Africa. Ecol Appl 17:S144-S164

Oczkowski A, Markham E, Hanson A (2014) Carbon stable isotopes as indicators of coastal eutrophication. Ecol Appl 24:457-466

Orlandi L, Bentivoglio F, Carlino P (2014) $\delta^{15} \mathrm{~N}$ variation in Ulva lactuca as a proxy for anthropogenic nitrogen inputs in coastal areas of Gulf of Gaeta (Mediterranean Sea). Mar Pollut Bull 84:76-82

Peterson BJ, Fry B (1987) Stable isotopes in ecosystem studies. Annu Rev Ecol Syst 18:293-320

Richardson CJ (2010) The everglades: North America's subtropical wetland. Wetl Ecol Manag 18:517-542

Savage C (2005) Tracing the influence of sewage nitrogen in a coastal ecosystem using stable nitrogen isotopes. Ambio 34:145-151

Sklar F, McVoy C, VanZee R (2002) The effects of altered hydrology on the ecology of the Everglades. The Everglades, Florida Bay, and Coral Reefs of the Florida keys, pp 39-82

Sklar FH, Chimney MJ, Newman S et al (2005) The ecological-societal underpinnings of Everglades restoration. Front Ecol Environ 3:161-169

Smith SM, Leeds JA, McCormick PV (2009) Sawgrass (Cladium jamaicense) responses as early indicators of low-level phosphorus enrichment in the Florida Everglades. Wetl Ecol Manag 17:291-302

Wang J, Gu B, Ewe SML (2015) Stable isotope compositions of aquatic flora as indicators of wetland eutrophication. Ecol Eng 83:13-18

Wright AL, Reddy KR, Newman S (2008) Biogeochemical response of the Everglades landscape to eutrophication. Global J Environ Res 2:102-109

Zhang W, Lei Q, Li Z (2016) Temporal variation of nitrogen balance within constructed wetlands treating slightly polluted water using a stable nitrogen isotope experiment. Environ Sci Pollut Res 23:2677-2683

\section{Publisher's Note}

Springer Nature remains neutral with regard to jurisdictional claims in published maps and institutional affiliations.

\section{Submit your manuscript to a SpringerOpen ${ }^{\circ}$ journal and benefit from:}

- Convenient online submission

- Rigorous peer review

- Open access: articles freely available online

- High visibility within the field

- Retaining the copyright to your article

Submit your next manuscript at $\boldsymbol{\nabla}$ springeropen.com 